\title{
A Bud Shaped Solar Heating Box
}

\author{
Yingxue Li \\ School of North China Electric Power University, Baoding 071000, China; \\ snowq1@outlook.com
}

Keywords: Heating lunch box, solar energy, reflective board, vacuum heat collector, energy-efficient

\begin{abstract}
The bud shaped solar heating box comprises a box body, a one-way pressure release on the box cover, reflective board, vacuum heat collector, a fixed ring, ellipsoidal hinge and other parts. This product uses vacuum collector to convert the solar energy ,which is from the high efficiency of the reflector, into thermal energy to heat food, resulting in energy saving, emission reduction and the quality of people travel food improving. This product, which has the advantages of green energy saving, high efficiency, low cost, easy carrying, convenient use and so on, can be used in any place with the sunlight and it has a broad market space.
\end{abstract}

\section{Introduction}

Diet is the most basic and most important needs of human beings. In daily life, lunch boxes are the main choice for people to carry food. Therefore, a portable heating lunch box can provide garantees for people's health and more comfortable eating experience. At present, heating boxes are widely used in electric heating way. However, those electric heating lunch boxes cannot be used when people travel outdoor without electricity. In addition, the children, with the electric heating lunch box, will inevitably touch the power, and in this case, it is easy to lead to elecric shock hazard. So if the heating energy can be changed into clean, safe, pollution-free solar energy, the durability and safety of lunch box will be greatly improved.

Currently, the existing solar boxes can be divided into two basic categories: one is photoelectric conversion, the other is the photothermal conversion. The former combines a solar cell and a lunch box, converting the solar energy into electric energy, and then heat the food in an electrically heated way. This design is relatively simple, but the energy conversion efficiency is low, probably in the $10 \% \sim 18 \%$. The latter apply a layer of heat absorbing coating outside the box surface, which can directly convert sunlight into thermal energy, and the energy efficiency of this way can reach $50 \% \sim 60 \%$. Although this number is higher, the energy absorbed by coating is less, due to the surface area of the lunch box is limited. In order to solve this problem, we use a retractable folding reflector to increase the amount of solar light. We design this reflective plate into a petal shape. It shows a flower shape at work, and folds to be a bud shape at rest. Compared with the traditional electric heating lunch box, the solar box is not only better safety and beauty, but also achieve the goal of energy saving and emission reduction. Besides, it provides a new and simple method for heating the outdoor food. 


\section{Design Scheme}

\section{1 . Glass Vacuum Heat Collector}
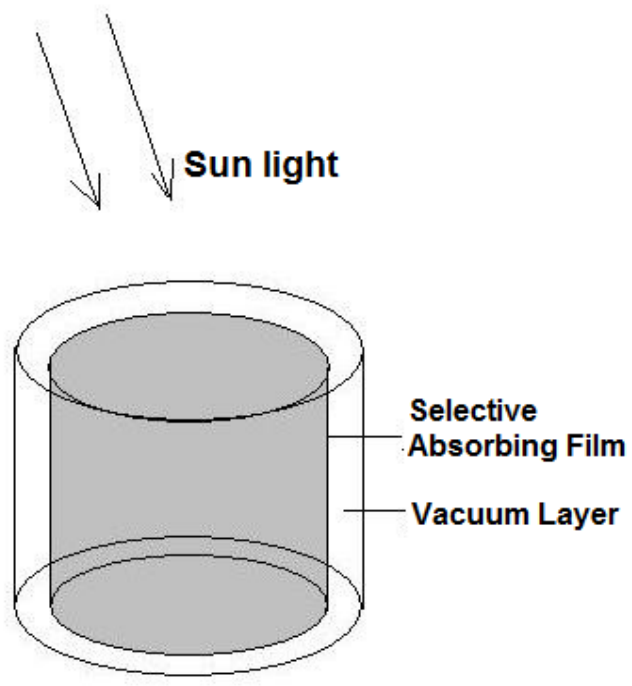

Figure 1

As shown in Figure 1, the glass vacuum heat collector has two layers-inside and outside, and the material is the glass. The top surface and the side wall of the inner layer are coated with a high absorption rate solar light selective absorbing film. A vacuum layer is arranged between the inner and the outer layers, which can effectively reduce heat loss and improve the efficiency of the photothermal conversion. In the work, the sun irradiate to the selective absorbtion coating on the inner layer, through the outer layer, and the solar radiation energy is converted into heat energy.

\subsection{Reflective Board}

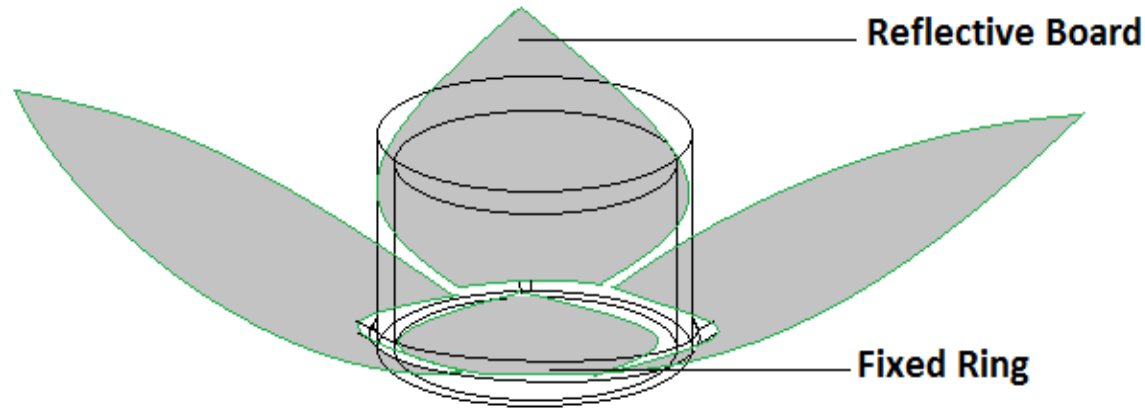

Figure 2

As shown in Figure 2, a fixed ring is adhered on the periphery of the heat collector which is mentioned above. The fixed ring can be connected with four petal shaped reflective board, in order to increase the area of sunlight, and to gather the light in the vacuum collector as much as possible.

The board choose the aluminized film as reflective material because of its light weight and high efficiency. The reflectivity of this film is about 10 percent higher than aluminum mirror, and although easy to aging, the replacement is convenient. So this materia is more appropriate to plated on the reflector. 


\subsection{Fixed Ring}

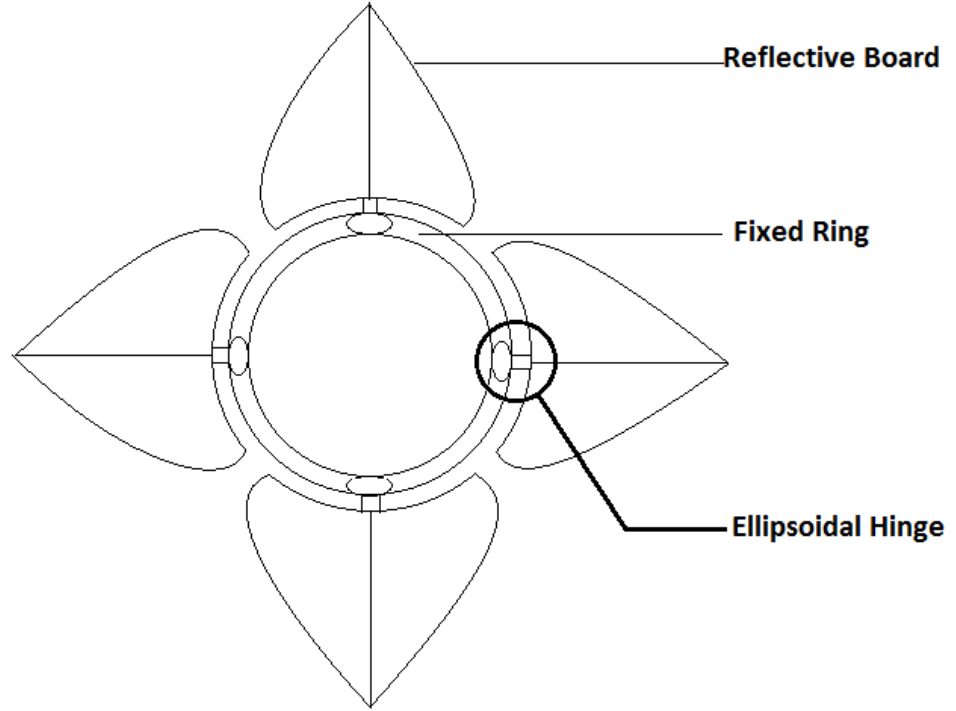

Figure 3

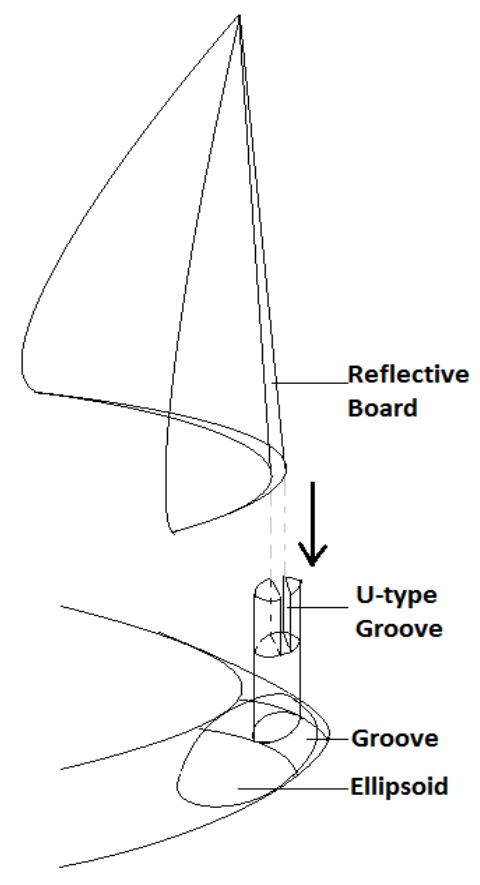

Figure 4

As is shown in Figure 3, the reflective board and vacuum heat collector are connected by a fixed ring and four ellipsoidal hinges. The fixed ring is glued on the collector by glass adhesive, and four grooves are arranged on the ring, where the ellipsoid hinge is placed in. The placement method of the hinge is shown in Figure 4. In addition, one end of the hinge provides with a U-type groove connecting reflective board, which can make the board open freely in the groove range.

\subsection{General Design Chart}

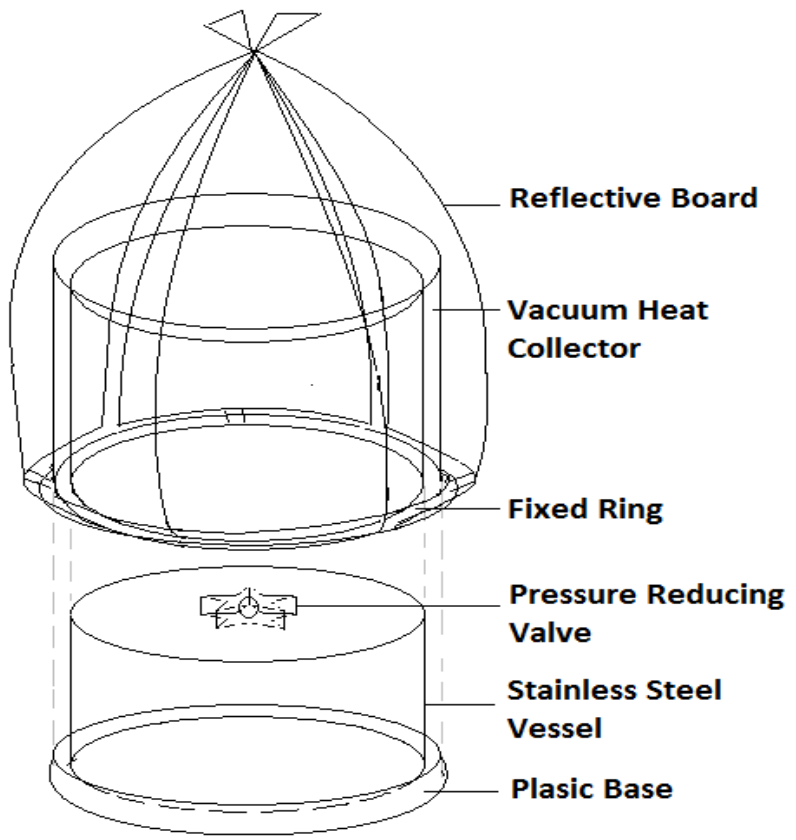

Figure 5

The general design chart is shown in Figure 5. In addition to the above devices, there is a stainless steel vessel in this heating box. There is a pressure reducing valve on the upper surface of this vessel and a heat preservation base on the bottom. The base uses double-layer plastic material, and the top surface is provided with a clamping groove -for fixing the stainless steel utensil, and an 
inner screw thread which can be matched with the external thread at the bottom of the collector. The base can prevent heat loss during heating, and after heating, users can unscrew the base to take out the vessel, avoiding scalds caused by excessive tempreture.

\section{Comparison}

Here is a table comparing the characteristics of different types of the heating boxes.As is shown in Table 1.

Table 1 Comparison of Four Kinds of Boxes

\begin{tabular}{|c|c|c|c|c|}
\hline & $\begin{array}{l}\text { Ordinary } \\
\text { Heating Box }\end{array}$ & Solar Battery Box & $\begin{array}{c}\text { Ordinary Solar } \\
\text { Energy Coating } \\
\text { Box } \\
\end{array}$ & $\begin{array}{l}\text { Bud Shaped } \\
\text { Solar Box }\end{array}$ \\
\hline $\begin{array}{c}\text { Energy } \\
\text { Conversion } \\
\text { Mode }\end{array}$ & $\begin{array}{l}\text { Electric energy } \\
\text { is converted into } \\
\text { heat energy }\end{array}$ & $\begin{array}{c}\text { Solar energy is } \\
\text { converted to electric } \\
\text { energy, and then to } \\
\text { heat energy. }\end{array}$ & $\begin{array}{l}\text { Solar energy is } \\
\text { converted into } \\
\text { heat energy }\end{array}$ & $\begin{array}{r}\text { Solar en } \\
\text { convert } \\
\text { heat eI }\end{array}$ \\
\hline Adva & $\begin{array}{l}\text { High electric } \\
\text { heating } \\
\text { conversion } \\
\text { efficiency }\end{array}$ & $\begin{array}{c}\text { The solar energy can } \\
\text { be stored in the } \\
\text { battery. }\end{array}$ & $\begin{array}{l}\text { High photo } \\
\text { thermal } \\
\text { conversion } \\
\text { efficiency }\end{array}$ & $\begin{array}{l}\text { High utilization } \\
\text { rate of solar } \\
\text { energy and large } \\
\text { light area }\end{array}$ \\
\hline Disadvantages & $\begin{array}{l}\text { Must ensure the } \\
\text { power supply }\end{array}$ & $\begin{array}{l}\text { Low photoelectric } \\
\text { conversion efficiency } \\
\text { and battery pollution }\end{array}$ & $\begin{array}{l}\text { Small light area } \\
\text { and long heating } \\
\text { time }\end{array}$ & $\begin{array}{c}\text { High-quality } \\
\text { manufacturing } \\
\text { technology }\end{array}$ \\
\hline
\end{tabular}

\section{Conclusion}

With the growth of the national economy, people's living conditions is increasing and people will prefer outdoor sports compared with the previous. For camping enthusiasts, the portable and readily available solar energy boxes will be their best choice. Even if for those people who don't like to go for an outing, the high-efficiency lunch boxes are also the preferred, especially for outdoor workers.

This design thinking from the user's perspective, to achieve humanization and high efficiency, every detail is carefully devised. And the safety and service life of the heating boxes have been improved prominently. Moreover, the design has the adwantages of energy saving, enviromnment-frendly, carrying and operating conveniently and short heating time, which has a great market space and promotion value.

\section{Reference}

[1]. Dehua Xiong, Wei Chen, Hong Li. Research progress of selective absorption coatings for solar thermal conversion [J]. Science and Technology Review. Vol. 32 (2014) No. 9, p. 50-58

[2]. Zhiqiang Yin, Xiyuan Yan, Tenghua Chen. The Thermal Performance of the Solar Absorption Coating and Vacuum Tube[J]. Acta Energiae Solaris Sinica. Vol. 17(1996)No. 1,p.50-56

[3]. Wanli Hu, Changyou Li. The solar energy selective absorbing coating[J]. Renewable Energy. Vol. 121(2005)No.3,p.44-46

[4]. "Purchase, use and maintenance of home appliances in the countryside" Editorial board. Solar water heater, solar cooker[M]. University of Electronic Science and Technology Press, 2010, p. 49-196. 